\title{
Effects of fragmentation on density and population genetics of a threatened tree species in a biodiversity hotspot
}

\author{
S. M. Ganzhorn ${ }^{1,2, *}$, B. Perez-Sweeney ${ }^{1}$, W. W. Thomas $^{2}$, F. A. Gaiotto ${ }^{3}$, J. D. Lewis ${ }^{1}$ \\ ${ }^{1}$ Louis Calder Center - Biological Field Station, and Department of Biological Sciences, Fordham University, Armonk, \\ NY 10504, USA \\ ${ }^{2}$ The New York Botanical Garden, Bronx, NY 10458, USA \\ ${ }^{3}$ Departamento de Ciências Biológicas - Universidade Estadual de Santa Cruz (UESC), Ilhéus, BA 45662-900, Brazil
}

\begin{abstract}
Fragmentation threatens biodiversity globally. Manilkara maxima (Sapotaceae) is listed by the IUCN as threatened and is an economically and ecologically important tree species endemic to the Atlantic forest of southern Bahia, Brazil, a biodiversity hotspot. The objectives of this study were to examine the effect of fragment size on density and genetic diversity of this threatened species. We surveyed and sampled 222 individuals across 2 large forest sites and 1 site comprising 8 small fragments. We focused on 5 microsatellite loci that provided comparable genetic information (average 21 alleles locus ${ }^{-1}$ ) as 2 congeners in other studies. Fragment size accounted for 71 and $56 \%$ of density variation in adult and sapling trees, respectively, but did not account for genetic variation. Rather, density accounted for $80 \%$ of allelic diversity and $70 \%$ of allelic richness in both life stages. The lack of relationship between genetic diversity and fragment size was driven in part by a co-variation in density and genetic diversity in 25 ha fragments. These small forests can have high densities of M. maxima, and in turn, can have as much genetic diversity and conservation value as larger fragments. However, the larger fragments are of unique conservation value because they hold the greatest number of reproductively mature individuals, the ones necessary for the recruitment of new individuals. Our results suggest that relatively high levels of gene flow are contributing to the high genetic diversity of saplings found in some of the small fragments.
\end{abstract}

KEY WORDS: Bahia - Brazil · Manilkara maxima · Population genetics · Fragmentation · Neotropics $\cdot$ Sapotaceae

\section{INTRODUCTION}

Fragmentation of continuous habitats into smaller, isolated fragments is recognized as one of the greatest threats to biodiversity (Fahrig 2003). The acute effects of fragmentation have caused many species to exist only as small, isolated populations and be listed on The International Union for Conservation of Nature (IUCN) Red List of Threatened Species (IUCN 2013). The predicted genetic consequences of fragmenting

\footnotetext{
*Corresponding author: ganzhorn@fordham.edu
}

tree species populations include reduced population size and gene flow resulting in a loss of alleles, which over successive generations will lead to increased genetic drift, reduced heterozygosity, increased inbreeding, increased genetic differentiation among populations, and potentially lower fitness (Young et al. 1996, Nason \& Hamrick 1997, Aguilar et al. 2008). However, such effects are not always predictable, in part because some species have naturally scattered distributions and low densities, are long-lived and ex-

() The authors 2015. Open Access under Creative Commons by Attribution Licence. Use, distribution and reproduction are unrestricted. Authors and original publication must be credited. 
perience long-distance dispersal and may thus be less affected by fragmentation, particularly relatively recent fragmentation (Kramer et al. 2008, Bacles \& Jump 2011). Our study species, Manilkara maxima T.D. Penn. (Sapotaceae), shares the aforementioned characteristics and is listed by the IUCN as 'Vulnerable' (Pires-O'Brien 1998).

It is important to examine the effects of fragmentation on $M$. maxima and estimate its baseline of genetic diversity because it is an economically and ecologically important species. According to reports (Pennington 1990, Jardim 2003) and herbarium collections, M. maxima is endemic to ca. $350 \mathrm{~km}$ of forest in southern Bahia (see Fig. 1) in the highly fragmented Brazilian Atlantic forest biodiversity hotspot (Myers et al. 2000). Only $18 \%$ of the original forest remains in this region, and $95 \%$ of the remaining fragments are $<100$ ha (Landau et al. 2008, Ribeiro et al. 2009). M. maxima is economically important as a timber source and is selectively logged (S. M. Ganzhorn pers. obs.) due to its insect- and fungus-resistant wood (Pennington 2004). Additionally, M. maxima is ecologically important to the endangered golden-headed lion tamarin (GHLT) Leontopithecus chrysomelas as a source of dietary nectar (Raboy \& Dietz 2004), and was identified as an 'extremely valuable' tree species for GHLT conservation (Oliveira et al. 2010).

We performed population genetic analysis on M. maxima to better understand the effects of fragmentation on density and genetic diversity of a lowdensity tree species with a scattered distribution and long distance dispersal. Greater understanding of the effects of fragmentation on low-density species, particularly those at risk of extinction, is critical for developing science-based conservation and restoration projects. We used microsatellite analysis of 5 loci to determine (1) if fragment size affects the density and genetic diversity of adults and saplings, and (2) if density affects the genetic diversity of adults and saplings. Our genotype data contained a large number of alleles that were similar to those found in 2 other congeners (Azevedo et al. 2005, Moraes et al. 2013), underscoring the informative value of our 5 loci. We defined adult trees as plants $>1 \mathrm{~cm}$ diameter at breast height (dbh), and saplings as plants $\leq 1 \mathrm{~cm}$ dbh and $\geq 20 \mathrm{~cm}$ total height (ht). Tropical trees $\leq 1 \mathrm{~cm}$ dbh are estimated to be $<20 \mathrm{yr}$ old (Welden et al. 1991, Hubbell 2004). Most of the fragmentation of the study area occurred in the early 1970s (Mori \& Silva 1979, Mendonça et al. 1994), about 35 yr before the present study. Accordingly, these life stages enabled us to conservatively estimate indices of population genetic diversity for adults (>20 yr) and saplings $(<20 \mathrm{yr})$ that were established pre- and postfragmentation, respectively.

\section{MATERIALS AND METHODS}

\section{Study species}

Manilkara maxima is listed as 'Vulnerable' by the IUCN due to its restricted range, habitat loss, and fragmentation (Pires-O'Brien 1998). M. maxima grows to $30 \mathrm{~m}$ in height with a diameter of $100 \mathrm{~cm}$. This species can be identified by the presence of latex, broad cuneiform leaves with abaxial appressed ferruginous indumentum, and solitary white flower with 6 staminodes (Pennington 1990). The genus Manilkara is slow-growing (O'Farrill et al. 2006) and has a mating system which is predominately outcrossed by pollen vectors that include flies, bees, bats, and primates, and has seed vectors that include birds, bats, and primates (Pennington 2004, Azevedo et al. 2007). Bat and bird species travel between forest fragments and contribute to long-distance dispersal (Howe \& Smallwood 1982, Cosson et al. 1999, Shilton et al. 1999).

\section{Study area}

The study was conducted during 2009 in southern Bahia, Brazil, in the Nova Esperança Forest, the Una Ecopark, and the Lemos Maia Experimental Station (Fig. 1). These 3 forests are protected from logging and appear to be well preserved, with a mature forest structure (a $25 \mathrm{~m}$ high canopy and numerous large epiphytes and lianas), and a mean canopy cover of $94 \%$. This region has a monthly average temperature of $24^{\circ} \mathrm{C}$, annual average relative humidity of 80 to $90 \%$, and evenly distributed annual average precipitation of 1400 to $2000 \mathrm{~mm}$ (Rocha 1976, Mori et al. 1983, Landau et al. 2003). The natural vegetation of the study area is classified as lowland tropical moist forest or, locally, tabuleiro forest (Thomas \& Barbosa 2008).

\section{Study sites}

The Nova Esperança (NE) study site (Fig. 1) is 200 ha of privately owned forest $50 \mathrm{~km}$ north of Ilhéus, Bahia, Brazil (14²0' 31" S, 3902' 33" W). The Una Ecopark (UE) study site (Fig. 1) is a 400 ha Private Natural Heritage Reserve owned and managed by the Institute for Social and Environmental Studies 


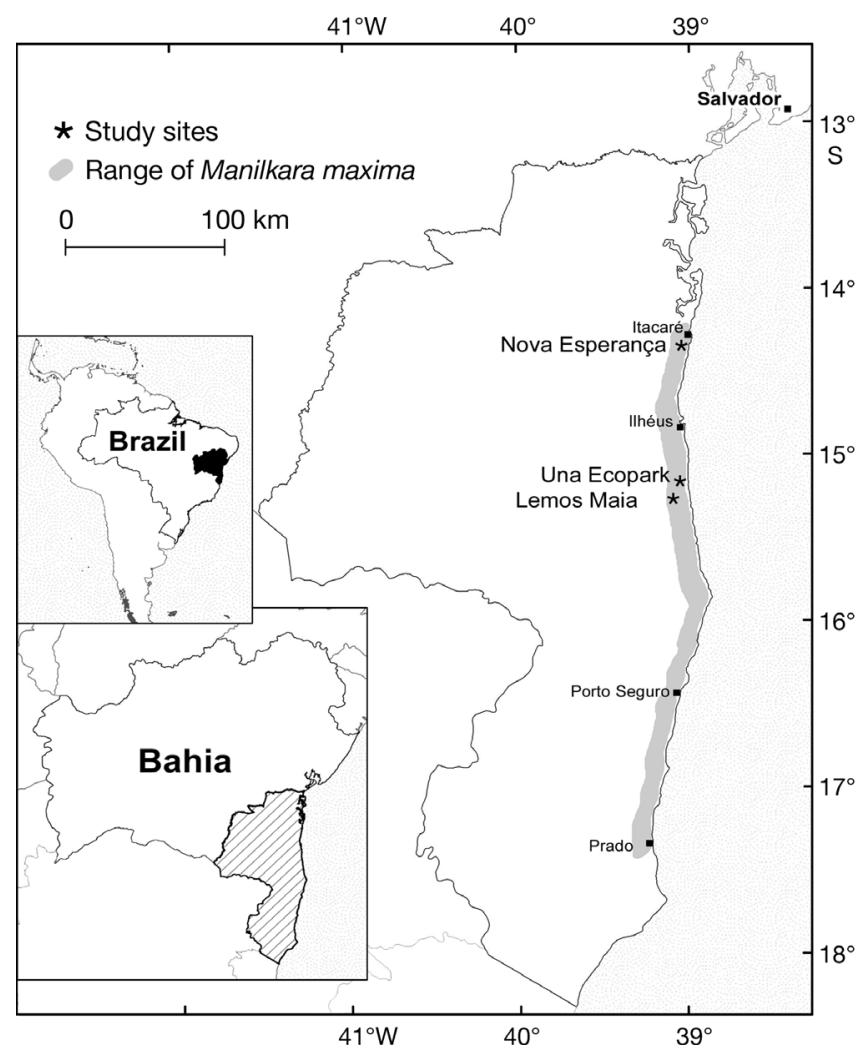

Fig. 1. Locations of study sites ( $*$; Nova Esperança, Una Ecopark, and Lemos Maia) and cities (ם). The range of Manilkara maxima is shaded in solid gray in the main map. Insets show the location of Bahia (black) and southern Bahia region (strippled)

in Southern Bahia (IESB), located $45 \mathrm{~km}$ south of

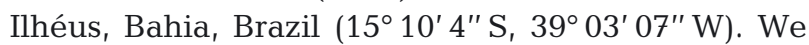
classified both of these sites as large forest fragments for this study.

The Lemos Maia Experimental Station (LM) study site (Fig. 1 \& Fig. S1 in the Supplement at www. int-res.com/articles/suppl/n026p189_supp.pdf) is a 400 ha agricultural field station owned and managed by the Executive Cocoa Planting Commission (CEPLAC) located $52 \mathrm{~km}$ south of Ilhéus, Bahia,

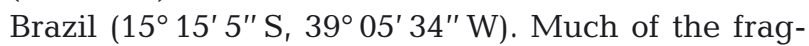
mentation in southern Bahia occurred in the early 1970s (Mendonça et al. 1994), and many forests are remnants of this recent fragmentation. The station was established in 1975 (J. I. Lacerda pers. comm.), and is a mosaic of recently fragmented forests, surrounded by dirt roads, agricultural fields, regenerating forests, and agroforests. We selected 8 forest fragments $(5,10$, and 25 ha) to survey (hereafter LM1, LM2, LM3...) from the small forest fragment site (LM): three 25 ha forests, two 10 ha forests, and three 5 ha forests (Fig. S1). Forest fragment distance to closest forest (large fragment $>100$ ha) ranged from 1.5 to $3.5 \mathrm{~km}$ and had a mean distance of $2.6 \mathrm{~km}$. The distance among fragments ranged from 0.2 to $1.6 \mathrm{~km}$ and had a mean distance of $0.5 \mathrm{~km}$.

\section{Sample collection and density estimate}

One 10 ha sampling area $(250 \times 400 \mathrm{~m})$ was surveyed at each of the 2 large fragment sites (NE and UE) and at each of the 25 ha forests for the study species. The one 10 ha sampling area was used at both large fragment sites (NE and UE) instead of smaller replicated plots to sample enough individuals at the large fragment sites (NE and UE), due to the low density and patchy distribution of this species. The entire forest area was surveyed for the study species at each of the two 10 ha forests and three 5 ha forests. In total, we mapped and sampled 222 trees (adults $>1.0 \mathrm{~cm}$ $\mathrm{dbh}$ and saplings $\leq 1 \mathrm{~cm}$ dbh and $\geq 20 \mathrm{~cm} \mathrm{ht}$ ) from the 3 study sites ( $N E, N=60 ; U E, N=54$; and $L M, N=108$ ), a sampling regime that represented $>5 \%$ (and in some cases $100 \%$ ) of the area from each forest, with one exception, where it represented $2.5 \%$ of the total area (Table S1 in the Supplement at www.int-res. com/articles/suppl/n026p189_supp.pdf). Density (D) was calculated as $\mathrm{N}$ (no. of individuals per sample area)/sample area. Cambium and leaf material were collected and placed in re-sealable plastic bags with 50 to $60 \mathrm{~g}$ of self-indicating silica gel (Chase \& Hills 1991, Colpaert et al. 2005).

\section{Genetic analysis}

Genomic DNA was extracted from cambium and leaves of $M$. maxima using the DNeasy ${ }^{\mathrm{TM}}$ Plant Mini Kit (Qiagen). Plant material was crushed in liquid nitrogen for tissue homogenization prior to DNA extraction. The DNeasy ${ }^{\mathrm{TM}}$ extraction protocol was performed with the addition of $2 \%$ PVP-40 (polyvinyl-pyrrolidone) to the lysis buffer.

The 5 microsatellite loci used in this study (Table 1) were selected from those developed for the congener Manilkara huberi Ducke (Azevedo et al. 2005). A multiple-tailed M13 primer method was used for genotyping microsatellite loci by synthesizing an additional modified 16 to $17 \mathrm{bp}$ tail (Table 1) to the 5' -end of the forward primer for each primer pair (Oetting et al. 1995). The polymerase chain reaction (PCR) had a final volume of $10 \mu \mathrm{l}$, and contained $1.0 \mu \mathrm{l}$ of $10 \times$ buffer (200 mM Tris- $\mathrm{HCl} \mathrm{pH} 8.8,100 \mathrm{mM} \mathrm{KCl}, 100 \mathrm{mM}$ $\left(\mathrm{NH}_{4}\right)_{2} \mathrm{SO}_{4}, 20 \mathrm{mM}\left(\mathrm{MgSO}_{4}\right)_{7} \mathrm{H}_{2} \mathrm{O}, 1 \%$ (v/v) Triton X- 
Table 1. Five microsatellite loci characteristics for 222 Manilkara maxima individuals: locus identifications; repeat motif; oligonucleotide primer sequences; fragment sizes $(\mathrm{bp})$; annealing temperatures $\left(T_{\mathrm{a}}\right)$; number of alleles $(A)$; observed heterozygosity $\left(H_{\mathrm{o}}\right)$; expected heterozygosity $\left(H_{\mathrm{e}}\right)$; inbreeding coefficient $\left(F_{\mathrm{IS}}\right)$; and null allele frequency. Mean: null alleles corrected by Brookfield method; Mean ${ }^{\mathrm{a}}$ : with uncorrected null alleles

\begin{tabular}{|c|c|c|c|c|c|c|c|c|c|}
\hline Locus & $\begin{array}{c}\text { Repeat } \\
\text { motif }\end{array}$ & Primer sequence $\left(5^{\prime}-3^{\prime}\right)$ & $\begin{array}{l}\text { Size } \\
(\mathrm{bp})\end{array}$ & $\begin{array}{c}T_{\mathrm{a}} \\
\left({ }^{\circ} \mathrm{C}\right)\end{array}$ & A & $H_{\mathrm{o}}$ & $H_{\mathrm{e}}$ & $F_{\mathrm{IS}}$ & $\begin{array}{l}\text { Null } \\
\text { alleles }\end{array}$ \\
\hline Mh02 & $(\mathrm{CT})_{9}$ & $\begin{array}{l}\text { Fwd: CCT TTT CCC GCA AAT CCT } \\
\text { Rev: GGG CTG AGA CCA ATG TCA AT }\end{array}$ & 165-187 & 48 & 11 & 0.37 & 0.51 & 0.27 & 0.14 \\
\hline Mh08 & $(\mathrm{CT})_{11}$ & $\begin{array}{l}\text { Fwd: GTA ATG GGA GCC GTT TGA GA } \\
\text { Rev: CTG GGT AGC ATT TGT TGC AT }\end{array}$ & $181-229$ & 48 & 24 & 0.69 & 0.88 & 0.21 & 0.15 \\
\hline Mh12 & $(\mathrm{CT})_{9}(\mathrm{AC})_{6}$ & $\begin{array}{l}\text { Fwd: TGC GGA ACT GTG GAA AGA GT } \\
\text { Rev: ATC CAC AGC AAT GAC TGA CG }\end{array}$ & $175-235$ & 50 & 27 & 0.68 & 0.86 & 0.22 & 0.16 \\
\hline Mh17 & $(\mathrm{CT})_{13}$ & $\begin{array}{l}\text { Fwd: CAC GAT GAC CTC TCA GTG GA } \\
\text { Rev: CCT GTG TAT GCG TTC GAT TG }\end{array}$ & 192-265 & 50 & 21 & 0.45 & 0.54 & 0.17 & 0.14 \\
\hline Mh22 & $(\mathrm{CT})_{15}$ & $\begin{array}{l}\text { Fwd: CCC ATT ATA GCC CTC CAC CT } \\
\text { Rev: AGA GAG CAC ATG CAA GCT CA }\end{array}$ & $169-207$ & 50 & 27 & 0.76 & 0.86 & 0.11 & 0.07 \\
\hline Mean & & & & & 22 & 0.59 & 0.73 & 0.19 & 0.13 \\
\hline Mean $^{a}$ & & & & & 21 & 0.44 & 0.66 & 0.37 & \\
\hline
\end{tabular}

$100,50 \%(\mathrm{w} / \mathrm{v})$ sucrose, and $20 \mu \mathrm{g} \mathrm{ml} \mathrm{l}^{-1}$ bovine serum albumin (BSA)), $0.8 \mu \mathrm{l}$ of $0.2 \mathrm{mM}$ dNTP (New England Biolabs), $1.0 \mu \mathrm{l}$ of $0.25 \mu \mathrm{g} \mu \mathrm{l}^{-1} \mathrm{BSA}$ (New England Biolabs), $2.0 \mu \mathrm{l}$ of $5 \mathrm{M}$ betaine, $0.25 \mu \mathrm{l}$ of $10 \mu \mathrm{M}$ forward primer (Invitrogen), $0.5 \mu \mathrm{l}$ of $10 \mu \mathrm{M}$ reverse primer (Invitrogen), $0.5 \mu \mathrm{l}$ of $10 \mu \mathrm{M}$ dye primer, and $0.2 \mu \mathrm{l}$ of Taq DNA polymerase, $2 \mu \mathrm{l}$ of genomic DNA, and $1.75 \mu \mathrm{l}$ of nanopure water. The PCR amplifications were carried out on an Eppendorf Mastercycler Pro S thermocycler (Eppendorf North America) under the following conditions: $95^{\circ} \mathrm{C}$ for $2.5 \mathrm{~min}, 10$ cycles at $95^{\circ} \mathrm{C}$ for $30 \mathrm{~s}$, locus-specific annealing temperatures (Table 1), and $64^{\circ} \mathrm{C}$ extension for $1 \mathrm{~min}$, and then 30 cycles at $88^{\circ} \mathrm{C}$ for $30 \mathrm{~s}$, locus-specific annealing temperatures (Table 1), and $64^{\circ} \mathrm{C}$ extension for $1 \mathrm{~min}$. After 40 cycles, a final extension at $64^{\circ} \mathrm{C}$ for $10 \mathrm{~min}$ was used. The PCR products were sized with a Beckman Coulter CEQ 8800 sequencer using the Beckman Coulter DNA Size Standard Kit-400 and running the software package CEQ 8800 Genetic Analysis System v.9.0 (Beckman Coulter). The size analysis had a final volume of $40 \mu \mathrm{l}$, containing $0.5 \mu \mathrm{l}$ of size standard, PCR products according to tail type: $-\mathrm{R}$ tail $0.5 \mu \mathrm{l}_{\text {; }}$

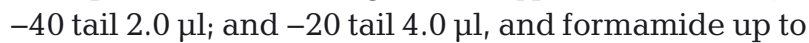
the final volume of $40 \mu \mathrm{l}$. Allele sizes were estimated using the GeneMarker Software v.1.90 (SoftGenetics).

\section{Data analysis}

Null alleles, stuttering, and allelic dropout were tested with Micro-Checker v.2.2.3 (Van Oosterhout et al. 2004). Errors due to stuttering or allelic dropout were not detected, but null alleles were found across all loci, ranging in frequencies from 7 to $16 \%$ (Table 1). Null alleles were corrected using the Brookfield method in Micro-Checker v.2.2.3 (Brookfield 1996, Van Oosterhout et al. 2006) and used for the genetic analyses. Data with corrected null alleles and uncorrected null alleles provided similar results. Deviation from Hardy-Weinberg Equilibrium (HWE) was examined with an exact test using the Markov chain (Levene 1949, Guo \& Thompson 1992), and linkage disequilibrium was assessed with a likelihood ratio test (Excoffier \& Slatkin 1998) in Arlequin v.3.5 (Excoffier et al. 2005). The genetic indices for the 5 polymorphic microsatellite loci of all 222 individuals were characterized for number of alleles $\operatorname{locus}^{-1}(A)$, $\%$ polymorphic loci $(P)$, observed heterozygosity $\left(H_{0}\right)$, expected heterozygosity $\left(H_{\mathrm{e}}\right)$, and the inbreeding coefficient $\left(F_{\mathrm{IS}}\right)$ using GenAlEx v.6.4 (Peakall \& Smouse 2006). Study-site specific $A, P, H_{\mathrm{e}} H_{\mathrm{o}}$ and number of private alleles $\left(P_{A}\right)$ were estimated using GenAlEx v.6.4 (Peakall \& Smouse 2006) and $F_{\mathrm{IS}}$ was estimated using 10000 permutations in Arlequin v.3.5 (Excoffier et al. 2005). The private allele method (Barton \& Slatkin 1986) was used to estimate the effective number of migrants generation ${ }^{-1}\left(N_{\mathrm{m}}\right)$ using GENEPOP v.4.2 (Raymond \& Rousset 1995, Rousset 2008). Additionally, allelic richness $\left(R_{\mathrm{S}}\right)$ was estimated by extrapolation to the largest sample size using the ARES package (van Loon et al. 2007) in R v.2.13 (R Development Core Team 2013). This method improves the accuracy of allelic richness estimates for small sample sizes and comparison of uneven sample sizes (Colwell et al. 2004), while rarefaction can result in relatively inaccurate estimates of richness for uneven sample sizes (Gotelli \& Colwell 2001). 
We tested for recent genetic bottlenecks of populations (Cornuet \& Luikart 1996) at the 3 study sites for both life stages by examining differences across loci between Hardy-Weinberg $H_{\mathrm{e}}$ and heterozygosity predicted at mutation-drift equilibrium from the observed number of alleles using the program BOTTLENECK v.1.2.02 (Piry et al. 1999). These differences were statistically tested under the infinite alleles model (IAM), the stepwise-mutation model (SMM), and the 2-phased model of mutation (TPM) using the Wilcoxon sign-rank test, which is traditionally the most powerful and commonly used test (Luikart et al. 1998). Since heterozygosity expected under mutation-drift equilibrium is more sensitive to the loss of low frequency alleles during a bottleneck, a significant excess of Hardy-Weinberg heterozygosity suggests a recent bottleneck (Cornuet \& Luikart 1996). The 5 populations that had sample sizes $\leq 2$ were excluded from this analysis.

An analysis of molecular variance (AMOVA) was performed using Arlequin v.3.5 (Excoffier et al. 2005). The AMOVA estimated genetic structure from $F$ statistics (Vogel et al. 1999) from a matrix of Euclidian squared distances of allelic content using a nonparametric procedure with 10000 permutations (Excoffier et al. 1992) based on a hierarchical model (Weir 1996) for both adult and saplings.

Population and genetic data variances were tested for homogeneity of variances using Levene's test (Levene 1960). All data were $\log _{10}$ (variable +1 ) transformed to meet statistical assumptions of homoscedasticity. The statistical relationships among forest area, density and genetic indices were examined using linear regression analysis. We examined the effects of forest area and density on genetic indices using ANCOVA, where forest area and density were covariates and genetic indices was the dependent variable. To examine the effects of life stage and density on genetic indices, we used ANCOVA generalized linear model (GLM) analysis, with life stage and density as covariates and genetic indices as the dependent variable. All statistical tests were calculated using SYSTAT v.13 software (Systat Software).

\section{RESULTS}

\section{Density}

There were no Manilkara maxima individuals in the LM5 5 ha forest and no $M$. maxima adults in the LM1 5 ha forest (Table S1 in the Supplement). Mean adult densities were 1.0 stems $\mathrm{ha}^{-1}$ for small forest fragments and 4.2 stems $\mathrm{ha}^{-1}$ for large fragments. Densities of adult trees increased with increasing forest size $\left(r^{2}=0.714, p=0.029\right.$; Fig. 2A).

As with the adults, mean sapling densities in the small fragments $\left(0.7\right.$ stems $\left.\mathrm{ha}^{-1}\right)$ were lower than those in large fragments (1.6 stems ha ${ }^{-1}$ ). Sapling tree density also increased with increasing forest size $\left(\mathrm{r}^{2}=0.565, \mathrm{p}=0.020\right.$; Fig. $\left.2 \mathrm{~B}\right)$. For these small fragments, the density sample is a good estimate of the actual density since the entire area was surveyed.

\section{Loci}

Null alleles were found across all loci, ranging in frequency from 7 to $16 \%$ (Table 1). Mean genetic indices with uncorrected and corrected null alleles were similar (Table 1). The results from the analyses were not different between data sets with uncorrected and corrected null alleles. Only analyses using corrected alleles are presented. The 5 microsatellite loci had a total of 110 alleles for the 222 individuals over all populations with a mean of 22 alleles locus ${ }^{-1}$
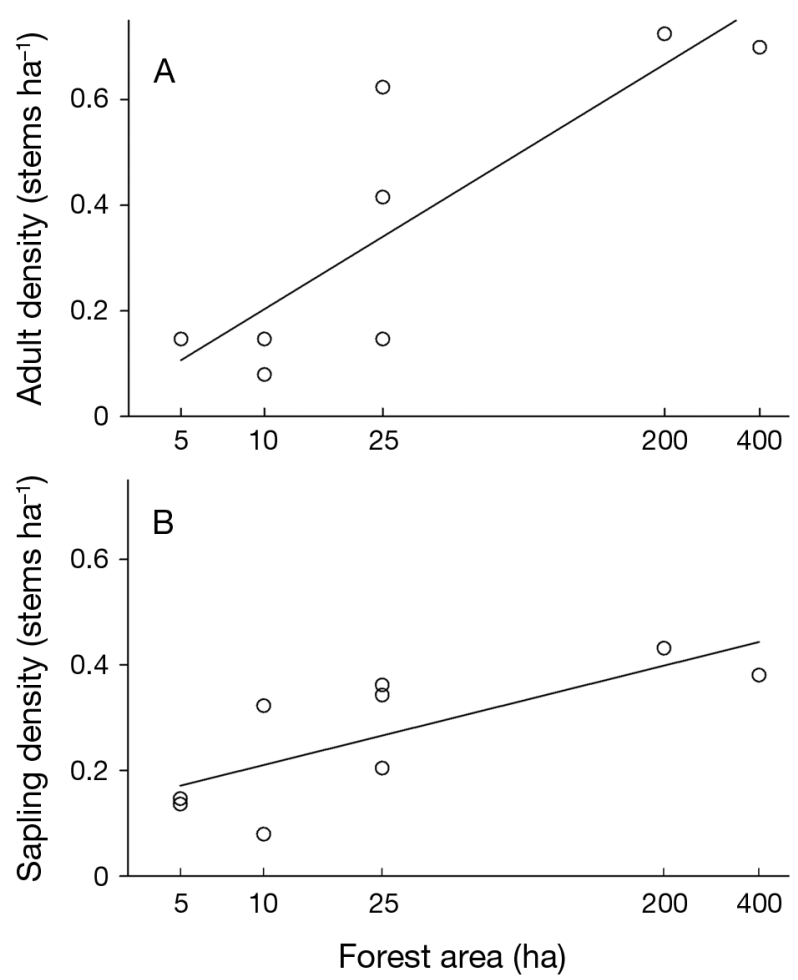

Fig. 2. (A) Linear regression of adult Manilkara maxima population mean density (stems ha ${ }^{-1}$ ) and forest area (ha) $\left(\mathrm{N}=8, \mathrm{r}^{2}=0.714, \mathrm{p}=0.029\right.$ ). (B) Linear regression of sapling population mean density (stems hal ${ }^{-1}$ ) and forest area (ha) $\left(\mathrm{N}=9, \mathrm{r}^{2}=0.565, \mathrm{p}=0.020\right)$. Note the change of scale on the $x$-axis. $\alpha=0.05$ 
(Table 1). A total of 28 private alleles (Table 2) were detected for both life stages, $86 \%$ of which had a frequency $<5 \%$. The mean $\%$ of polymorphic loci was $92 \%$ across all populations (Table 2). The 5 loci exhibited significant departure from HWE, but no pairs of loci had significant linkage disequilibrium. The values for $H_{\mathrm{o}}$ ranged from 0.37 to 0.69 and were lower than $H_{\mathrm{e}}$, which ranged from 0.51 to 0.88 indicating an excess of homozygotes across all loci (Table 1).

\section{Population genetics}

For the adults, a total of 98 alleles were found, ranging from 1.8 to 11.6 alleles locus ${ }^{-1}$ (Table 2), with large fragments averaging 8.0 alleles locus $^{-1}$ and small fragments averaging 5.7 alleles locus ${ }^{-1}$. Indeed, one of the 25 ha small fragments had the highest allelic diversity (LM8 $A=11.6$ ) and another 25 ha fragment (LM2 $A=10.2$ ) was similar to the large NE fragment $(A=10.2)$ (Table 2$)$. Adults in these same
3 sites had $53 \%$ of the total private alleles ( $\mathrm{NE}=8$, LM2 = 2, LM8 = 5; Table 2). Similarly, high adult allelic richness was found in the same two 25 ha small fragments (LM2 $R_{\mathrm{S}}=80$ and LM8 $R_{\mathrm{S}}=67.0$; Table 2). Adult trees did not exhibit a significant genetic bottleneck for any population except for one small forest fragment site, LM7, that exhibited a significant bottleneck using the IAM, SMM, or TPM ( $\mathrm{p}<$ 0.05). Adult $H_{\mathrm{o}}$ ranged from 0.40 to 0.69 (Table 2), with moderate values for both large $\left(H_{0}=0.56\right)$ and small fragments $\left(H_{0}=0.53\right)$. Gene diversity of adults (measured as $H_{\mathrm{e}}$ ) ranged from 0.30 to 0.84 , with moderately high values for the adults of both large $\left(H_{\mathrm{e}}=\right.$ $0.57)$ and small fragments $\left(H_{\mathrm{e}}=0.61\right)$ (Table 2). Adult $F_{\text {IS }}$ ranged from -0.08 to 0.52 (Table 2), and was lower in the large $\left(F_{\mathrm{IS}}=0.02\right)$ compared to the small fragments $\left(F_{\mathrm{IS}}=0.23\right)$. Significant inbreeding was found for adults at the NE, LM2, LM3, LM7, and LM8 populations (Table 2).

For the saplings, a total of 86 alleles were detected ranging from 1.8 to 9.4 alleles locus ${ }^{-1}$ (Table 2), with large fragments averaging 5.6 alleles locus $^{-1}$ and

Table 2. Mean population and genetic diversity indices $( \pm \mathrm{SE})$ of the 3 study sites $(\mathrm{NE}=$ Nova Esperança, UE = Una Ecopark, and LM = Lemos Maia Experimental Station), showing number of Manilkara maxima individuals in the sample area (N); density of stems ha ${ }^{-1}(D)$; percent polymorphic loci $(P)$; number of alleles per locus $(A)$; number of private alleles $\left(P_{A}\right)$; allelic richness $\left(R_{\mathrm{S}}\right)$; observed heterozygosity $\left(H_{\mathrm{o}}\right)$; expected heterozygosity $\left(H_{\mathrm{e}}\right)$; inbreeding coefficient $\left(F_{\mathrm{IS}}\right) .{ }^{*} \mathrm{p}<0.05,{ }^{* *} \mathrm{p}<0.01$, ${ }^{* * *} \mathrm{p}<0.001$. Mean: null alleles corrected by Brookfield method; Mean ${ }^{\mathrm{a}}$ : with uncorrected null alleles

\begin{tabular}{|c|c|c|c|c|c|c|c|c|c|}
\hline Study site & $\mathrm{N}$ & $D$ & $P$ & $A$ & $P_{A}$ & $R_{\mathrm{S}}$ & $H_{\mathrm{o}}$ & $H_{\mathrm{e}}$ & $F_{\text {IS }}$ \\
\hline \multicolumn{10}{|l|}{ Large fragments } \\
\hline NE Adult & 43 & 4.3 & 100 & $10.2(1.50)$ & 8 & $77.7(2.87)$ & $0.58(0.09)$ & $0.65(0.11)$ & $0.11^{* *}$ \\
\hline NE Sapling & 17 & 1.7 & 100 & $7.0(1.30)$ & 1 & $35.0(1.91)$ & $0.64(0.06)$ & $0.67(0.08)$ & 0.08 \\
\hline UE Adult & 40 & 4.0 & 100 & $5.8(1.11)$ & 2 & $50.1(0.93)$ & $0.54(0.15)$ & $0.49(0.14)$ & -0.08 \\
\hline UE Sapling & 14 & 1.4 & 80 & $4.2(0.86)$ & 0 & $22.8(1.14)$ & $0.50(0.14)$ & $0.47(0.13)$ & -0.03 \\
\hline \multicolumn{10}{|l|}{ Small fragments } \\
\hline LM1 Adult & 0 & - & - & - & - & - & - & - & - \\
\hline LM1 Sapling & 2 & 0.4 & 100 & $2.6(0.40)$ & 0 & $12.0(0.59)$ & $1.00(0.00)$ & $0.58(0.05)$ & -0.54 \\
\hline LM2 Adult & 16 & 1.6 & 100 & $10.2(1.20)$ & 2 & $80.0(2.79)$ & $0.65(0.03)$ & $0.84(0.02)$ & $0.26^{* * *}$ \\
\hline LM2 Sapling & 13 & 1.3 & 100 & $9.4(1.36)$ & 3 & $53.4(3.24)$ & $0.71(0.05)$ & $0.82(0.01)$ & $0.17^{* *}$ \\
\hline LM3 Adult & 4 & 0.4 & 100 & $4.0(0.55)$ & 0 & $29.7(1.66)$ & $0.45(0.09)$ & $0.64(0.08)$ & $0.43^{*}$ \\
\hline LM3 Sapling & 6 & 0.6 & 100 & $4.6(0.81)$ & 3 & $29.5(1.55)$ & $0.53(0.14)$ & $0.62(0.10)$ & 0.22 \\
\hline LM4 Adult & 2 & 0.2 & 80 & $2.6(0.51)$ & 1 & $19.1(0.97)$ & $0.60(0.19)$ & $0.48(0.13)$ & 0.08 \\
\hline LM4 Sapling & 11 & 1.1 & 80 & $4.4(1.32)$ & 1 & $24.0(1.24)$ & $0.49(0.14)$ & $0.52(0.15)$ & 0.10 \\
\hline LM6 Adult & 2 & 0.4 & 60 & $1.8(0.37)$ & 0 & $12.1(0.26)$ & $0.40(0.19)$ & $0.30(0.13)$ & 0.01 \\
\hline LM6 Sapling & 2 & 0.4 & 60 & $1.8(0.37)$ & 0 & $12.0(0.59)$ & $0.28(0.11)$ & $0.30(0.13)$ & 0.01 \\
\hline LM7 Adult & 4 & 0.4 & 100 & $4.2(0.66)$ & 0 & $41.0(1.20)$ & $0.40(0.19)$ & $0.68(0.08)$ & $0.52^{* *}$ \\
\hline LM7 Sapling & 2 & 0.2 & 100 & $2.4(0.25)$ & 0 & $15.7(0.75)$ & $0.90(0.10)$ & $0.53(0.05)$ & -0.50 \\
\hline LM8 Adult & 32 & 3.2 & 100 & $11.6(1.10)$ & 5 & $67.0(2.50)$ & $0.69(0.04)$ & $0.75(0.05)$ & $0.09^{*}$ \\
\hline LM8 Sapling & 12 & 1.2 & 100 & $8.0(0.84)$ & 2 & $45.8(2.83)$ & $0.55(0.06)$ & $0.71(0.09)$ & $0.27^{* * *}$ \\
\hline Mean & & & 92 & $5.6(0.86)$ & & $37.0(1.59)$ & $0.59(0.12)$ & $0.59(0.09)$ & 0.07 \\
\hline Mean $^{a}$ & & & 85 & $5.1(0.39)$ & & $34.4(1.01)$ & $0.42(0.04)$ & $0.50(0.03)$ & 0.16 \\
\hline
\end{tabular}


small fragments averaging 4.7 alleles locus ${ }^{-1}$. Similar to the adults, saplings in 2 of the 25 ha forests had the highest allelic diversity (LM2 $A=9.4$, LM8 $A=8.0$; Table 2$)$ and allelic richness $\left(\mathrm{LM} 2 R_{\mathrm{S}}=53.4, \mathrm{LM} 8 R_{\mathrm{S}}=\right.$ 45.8; Table 2). Saplings in the three 25 ha fragments harbored $29 \%$ of the total private alleles (LM2 $=3$, LM3 $=3$, LM8 $=2$; Table 2). Hardy-Weinberg heterozygosity and expected heterozygosity at mutationdrift equilibrium did not differ significantly using the IAM, SMM, or TPM, suggesting a lack of evidence for recent genetic bottlenecks for the saplings. Sapling $H_{0}$ ranged from 0.28 to 1.00 (Table 2), with moderately high means for both large $\left(H_{\mathrm{o}}=0.57\right)$ and small fragments $\left(H_{0}=0.58\right)$. Similar to allelic diversity and richness, saplings in 2 of the 25 ha sites (LM2 $H_{\mathrm{e}}=0.82$ and LM8 $H_{\mathrm{e}}=0.71$ ) exhibited the highest gene diversity of all populations (Table 2). Sapling inbreeding also had a wide range $(-0.54$ to 0.52 ; Table 2) with low means for both large $\left(F_{\mathrm{IS}}=-0.03\right)$ and small fragments $\left(F_{\mathrm{IS}}=-0.04\right)$. Significant inbreeding was found for saplings in the LM2 and LM8 populations (Table 2).

There were no significant forest fragment size effects on the genetic indices for either adults or saplings. There were significant density effects for adult $A$ and $R_{\mathrm{S}}\left(\mathrm{r}^{2}=0.640, \mathrm{p}=0.017\right.$ and $\mathrm{r}^{2}=0.573, \mathrm{p}=$ 0.030 , respectively) and sapling $A_{1} R_{\mathrm{S}}$ and $F_{\mathrm{IS}}\left(\mathrm{r}^{2}=\right.$ $0.670, \mathrm{p}=0.007 ; \mathrm{r}^{2}=0.571, \mathrm{p}=0.019 ; \mathrm{r}^{2}=0.463, \mathrm{p}=$ 0.044 , respectively). When taking both density and area into account using an ANCOVA, $A$ and $R_{\mathrm{S}}$ did not vary clearly with area for either adults or saplings $(p>0.05)$, indicating that differences in density accounted for more of the variation among study sites than differences in area. The ANCOVA GLM showed significant density effects for $A\left(\mathrm{~N}=18, \mathrm{r}^{2}=\right.$ $0.802, \mathrm{p}=0.001), R_{\mathrm{S}}\left(\mathrm{N}=18, \mathrm{r}^{2}=0.702, \mathrm{p}=0.019\right)$, and no effect of life stage or an interaction of density and life stage for either adults or saplings (Fig. 3A,B). However, the ANCOVA GLM showed a significant interaction of density and life stage $(p=0.010)$ for $F_{I S}$ (Fig. 3C).

The AMOVA revealed that adult trees and sapling trees had moderate differentiation $\left(F_{\mathrm{ST}}=0.10\right.$ and 0.15 , respectively) among the 3 study sites. However, the low adult and sapling genetic differentiation among the 3 study sites was not significantly different (adults: $3.47 \%, p=0.194$; saplings: $5.12 \%$, $\mathrm{p}=0.213)$. Most of the adult and sapling genetic variation was found within the study sites (adults: $90.16 \%, p=0.001$; saplings: $84.95 \%, p=0.001$ ). However, the low adult and sapling genetic differentiation among the small fragments was significant (adults: $6.37 \%, \mathrm{p}=0.001$; saplings: $9.93 \%, \mathrm{p}=$
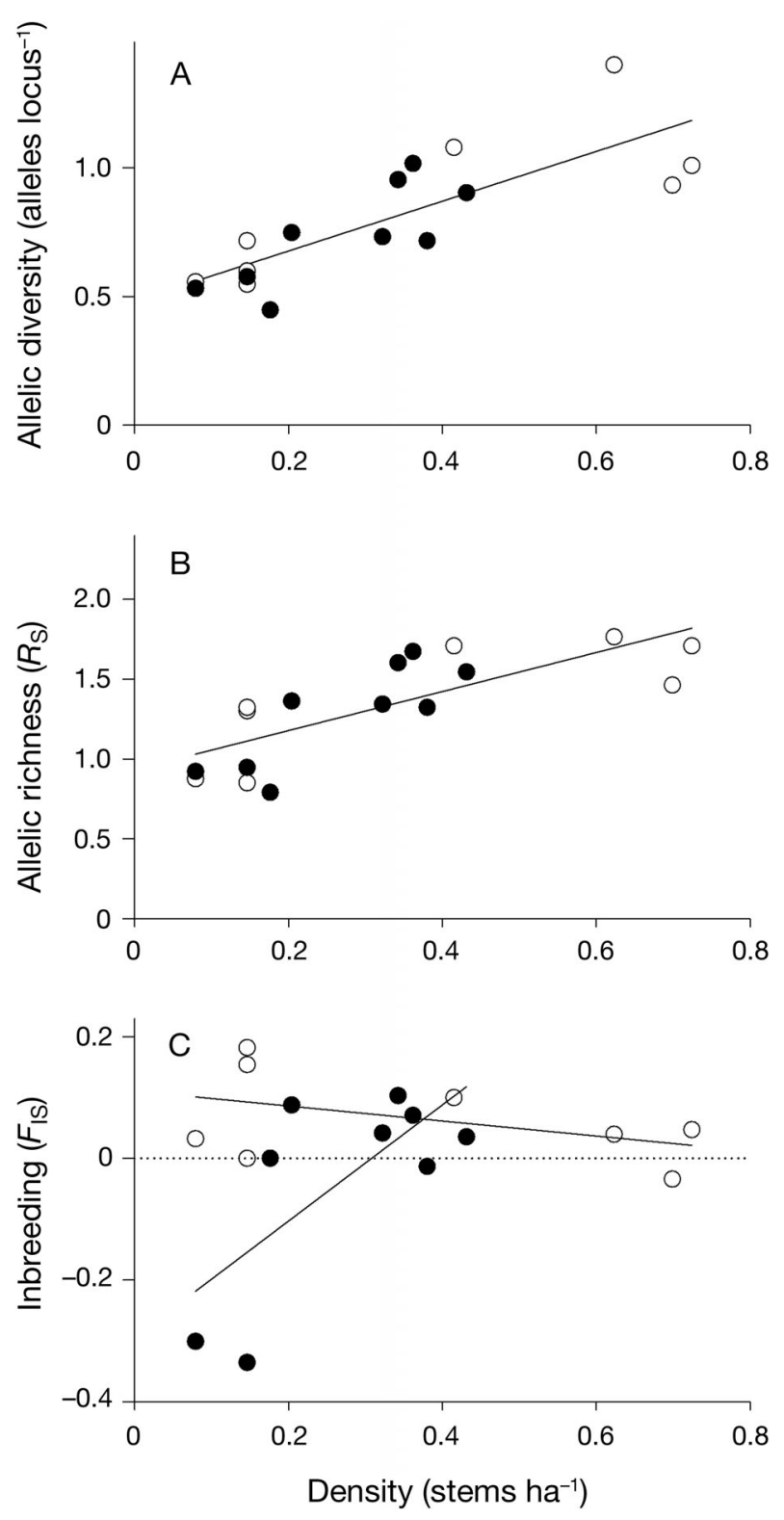

Fig. 3. Effects of Manilkara maxima life stage $(\mathrm{O}=$ adults; - = saplings) and density (stems ha ${ }^{-1}$ ) analyzed with ANCOVA generalized linear model. (A) Allelic diversity (alleles locus $\left.^{-1}\right)\left(\mathrm{N}=18, \mathrm{r}^{2}=0.802, \mathrm{p}=0.001\right)$. (B) Allelic richness $\left(R_{\mathrm{S}}\right)\left(\mathrm{N}=18, \mathrm{r}^{2}=0.702, \mathrm{p}=0.019\right)$. $(\mathrm{C})$ Inbreeding $\left(F_{\mathrm{IS}}\right)$ significant interaction of life stage and density $(\mathrm{N}=18$, $\mathrm{p}=0.010)$. All data were $\log _{10}($ variable +1$)$ transformed.

$$
\alpha=0.05
$$

0.001). The effective $N_{\mathrm{m}}$ across all populations using the private allele method (Barton \& Slatkin 1986) was $N_{\mathrm{m}}=6.49$ after correction for sample size. Additionally, the effective $N_{\mathrm{m}}$ after correction for sample size for adults was $N_{\mathrm{m}}=6.58$ and for saplings was $N_{\mathrm{m}}=5.23$. It generally only takes 1 migrant per population to homogenize a population. 


\section{DISCUSSION}

\section{Adults}

Our results suggest that while density decreased with decreasing forest fragment size, it varied substantially among 25 ha fragments. In addition, small fragments can harbor high levels of genetic diversity comparable to large fragments. Finally, density was a good predictor of genetic diversity and more reliable than fragment size, even though adult densities decreased with decreasing forest fragment size. This was primarily because one of the small fragments (LM8) had a stem density similar to that found in the large fragments (NE and UE). Additionally, adult trees in some small fragments (LM2 and LM8) had high levels of genetic diversity that were higher than or similar to the genetic diversity of trees found in large fragments (NE and UE).

The wide range in adult density across the 25 ha fragments ( 0.4 to 3.2 stems $\mathrm{ha}^{-1}$ ) may reflect the naturally (pre-fragmentation) scattered and patchy distribution of Manilkara maxima, as this variable distribution of trees is consistent with density expectations for spatially scattered populations unaffected by fragmentation (Kramer et al. 2008, Bacles \& Jump 2011), where more trees may be found in some fragments than others, even if the fragments are the same size and in close proximity. Despite their small size, some 25 ha forests are as important for maintaining M. maxima adult densities and genetic diversity as large forests. The adults in the LM2 25 ha fragment had the highest allelic diversity and richness, even though their density was half that of another 25 ha fragment (LMB) and the large fragments (NE and UE).

The heterozygosity, gene diversity and inbreeding observed for adults did not vary with forest size or density as we hypothesized, because the adult generation was established prior to the relatively recent forest fragmentation. One small population, LM7, comprising only 4 adults, had one of the highest gene diversity values $\left(H_{\mathrm{e}}=0.68\right)$, and adds support to the contention that small populations have conservation value for maintaining genetic diversity (Schneller \& Holderegger 1996, Finger et al. 2012). The adult mean inbreeding value found in the small fragments was higher than that reported by Azevedo et al. (2007) $\left(F_{\mathrm{IS}}=0.18\right)$ for a congener, Manilkara huberi, in a continuous forest, but lower than the mean inbreeding we found in the large fragments. However, the mean inbreeding for all the adults $\left(F_{\mathrm{IS}}=0.18\right)$ is consistent with that reported by Azevedo et al. (2007) for M. huberi. The relatively high inbreeding in some of the adult populations might be explained by sampling error or mating between related individuals that occurred pre-fragmentation.

The low and insignificant differentiation of the adult cohort indicates that only $3.47 \%$ of the genetic variation is distributed among the 3 study sites. Most of the distribution of the genetic variation was found within the study sites $(90.16 \%)$, suggesting extensive pre-fragmentation gene flow or common ancestry. Also, the relatively high gene flow $\left(N_{\mathrm{m}}=6.58\right)$ of the adults represents pre-fragmentation gene flow (Bossart \& Prowell 1998). Indeed, outcrossing species generally demonstrate high levels of genetic variation within populations and lower genetic differentiation among populations (Loveless \& Hamrick 1984), and similar results have been found in other fragmented Atlantic forest tree species (Seoane et al. 2000, 2005, Auler et al. 2002, Salgueiro et al. 2004, Silva et al. 2008).

\section{Saplings}

Similar to the adults, our results for saplings suggest that density decreased with decreasing forest size, but varied substantially among 25 ha fragments, that small fragments can harbor high levels of genetic diversity, and that density was a better indicator of genetic diversity than fragment size. As with the adult populations, 2 of the 25 ha fragments (LM2 and LM8) had sapling densities similar to the large fragments. Saplings in these same two 25 ha small fragments also had the highest allelic diversity and richness (Table 2). Also, as with the adults, the high density and genetic diversity of saplings in these small fragments provides support for the importance of small fragments for M. maxima.

The highest sapling genetic diversity detected in 2 of the 25 ha fragments may result from either longdistance dispersal from other forest fragments, or dispersal from adult trees within the LM fragmented area. Indeed, gene flow was relatively high for the saplings in the small fragments $\left(N_{\mathrm{m}}=5.23\right)$, and indicates recent gene flow (Yamamichi \& Innan 2012). The LM2 site had no reproductively mature adult trees in the sampled area (S. M. Ganzhorn unpubl. data) and is located between the LM8 site and the closest forest $>100$ ha at distances of $0.6 \mathrm{~km}$ and $1.5 \mathrm{~km}$, respectively. The LM2 site may offer an admixture of saplings between the LM8 and the closest forest $>100$ ha, and may act as a stepping 
stone to promote long-distance seed dispersal from larger to smaller fragments and a site for recruitment of younger trees from adult trees in LM8 and other larger fragments. The LM8 site had a similar adult density compared to the larger fragments (Table 2) with many reproductively mature individuals (S. M. Ganzhorn unpubl. data). The high quality matrix surrounding these sites, composed of advanced regenerating forests and agroforests, may help facilitate long-distance dispersal by organisms (e.g. bats, birds, and primates). The high sapling density and sapling allelic diversity in LM2 and LM8 makes these 25 ha fragments potentially important sources of genetic variation once the saplings mature.

The sapling $H_{\mathrm{o}}$ and $H_{\mathrm{e}}$ did not clearly vary with forest size or density. We expected such results because fragmentation in our study sites has been recent and genetic diversity declines only after successive generations (Young et al. 1996). Similar to the adults, 2 of the 25 ha fragments had the highest gene diversity (Table 2) and 1 small population, LM3, comprised of only 6 saplings, had one of the highest gene diversity values $\left(H_{\mathrm{e}}=0.62\right)$, supporting other studies that show that small populations of saplings have conservation value for genetic diversity (Schneller \& Holderegger 1996).

The mean sapling inbreeding in the large $\left(F_{\mathrm{IS}}=\right.$ $-0.02)$ and small $\left(F_{\text {IS }}=-0.04\right)$ fragments was low. These values were lower than those found for $M$. huberi $\left(F_{\mathrm{IS}}=0.24\right)$ progeny in an undisturbed habitat (Azevedo et al. 2007). However, we found significant sapling inbreeding in 2 of the 25 ha forests (Table 2), suggesting either sampling error or that mating between related individuals is occurring in some of the small forests. Similar to our results, Franceschinelli et al. (2007) found similar inbreeding values for the insect-pollinated and birddispersed Atlantic forest tree species Myrciaria floribunda among various sizes of fragments, suggesting that long-distance pollen and seed dispersal act as potential mechanisms for maintaining gene flow. Primates may also contribute to the low inbreeding given that GHLT, for example, can move between fragments (S. M. Ganzhorn pers. obs.) and have daily ranges (1.4 to $2.2 \mathrm{~km}$ ) that are within the inter-fragment distances $(0.2$ to $1.6 \mathrm{~km})$ in the LM study site (Raboy \& Dietz 2004). The GHLT lick nectar from the flower and may visit up to $60 \mathrm{M}$. maxima individuals in $1 \mathrm{~d}$ (B. E. Raboy pers. comm.). $M$. maxima comprises $5.3 \%$ of the GHLT frugivorous diet, but the seeds are spit out near the parent tree (Cardoso et al. 2011). The GHLT may be more important for long-distance pollen dispersal when consuming floral nectar.

Despite the moderate differentiation $\left(F_{\mathrm{ST}}=0.15\right)$ of the saplings, only $5.12 \%$ of the variation is found among the study sites, whereas $84.95 \%$ is found within the study sites. We expected this pattern because fragmentation has been recent relative to the generation time of these trees, and gene flow appears to be relatively high $\left(N_{\mathrm{m}}=5.23\right)$. Similar results of moderate differentiation have been found in other fragmented young Atlantic forest tree species (Seoane et al. 2000, 2005, Auler et al. 2002, Salgueiro et al. 2004, Silva et al. 2008).

\section{CONCLUSIONS}

Our baseline data suggest that larger forest fragments maintain higher tree densities of the threatened tree species Manilkara maxima; this is alarming considering only $5 \%$ of forests in this region are fragments $>100$ ha (Landau et al. 2008). However, some smaller, 'intermediate' sized forests also exhibited high tree densities and high levels of genetic diversity in both adults and saplings. Conserving reproductively mature individuals of M. maxima is necessary for the recruitment of new individuals into the population and for the species' long-term persistence, but we found that forests with few reproductively mature individuals have a promising amount of genetic diversity worth conserving as well. Our results suggest that relatively high levels of gene flow are contributing to the high genetic diversity of saplings found in some of the small fragments. Additionally, reforestation projects should use seeds from forests near project sites to preserve the genetic diversity found within local forests, even if the fragments are small. Finally, our results suggest that fragment size alone cannot be used as a predictor of genetic diversity; rather, tree density can offer a better predictor of diversity. Although density varied with fragment size (suggesting fragment size both directly and indirectly affects diversity), the results of our analyses of covariance suggest that density has a greater effect on allelic diversity and richness. For example, some small fragments exhibited genetic diversity comparable to large fragments, reflecting comparatively high density in these fragments. This study advances our understanding of how fragmentation affects the genetic diversity of this threatened tree species, and will aid in developing sciencebased biodiversity conservation and restoration projects. 
Acknowledgements. We thank The Brazilian Institute for the Environment and Renewable Natural Resources (IBAMA), for authorizing this research (13291-1) and The State University of Santa Cruz (UESC) for use of their laboratory. We thank the owners of the Fazenda Nova Esperança; Marcelo Araújo and Gabriel Santos from IESB; José Inácio Lacerda at CEPLAC for allowing access to the study sites; André Amorim and Cristiane Aguiar for access to the André Maurício Vieira de Carvalho Herbarium of the Cocoa Research Center (CEPEC); Larry Kelly, Damon Little, Gregory Plunkett, and Matthew Sewell at The New York Botanical Garden; and Diego Matos, Tilson Nascimento, Daniel Piotto, the late Talmon Santos, and Cristiane Tillia for field assistance. S.M.G. received support from Fordham University's GSAS, a Fordham Biology Alumni Research Fellowship, and The New York Botanical Garden.

\section{LITERATURE CITED}

Aguilar R, Quesada M, Ashworth L, Herrerias-Diego Y, Lobo J (2008) Genetic consequences of habitat fragmentation in plant populations: susceptible signals in plant traits and methodological approaches. Mol Ecol 17: 5177-5188

Auler NMF, Reis MS, Guerra MP, Nodari RO (2002) The genetics and conservation of Araucaria angustifolia: I. Genetic structure and diversity of natural populations by means of non-adaptive variation in the state of Santa Catarina, Brazil. Genet Mol Biol 25:329-338

> Azevedo V, Vinson C, Ciampi A (2005) Twelve microsatellite loci in Manilkara huberi (Ducke) standl (Sapotaceae), an Amazonian timber species. Mol Ecol Notes 5:13-15

- Azevedo VCR, Kanashiro M, Ciampi AY, Grattapaglia D (2007) Genetic structure and mating system of Manilkara huberi (Ducke) A. Chev., a heavily logged Amazonian timber species. J Hered 98:646-654

Bacles CF, Jump AS (2011) Taking a tree's perspective on forest fragmentation genetics. Trends Plant Sci 16:13-18

Barton NH, Slatkin M (1986) A quasi-equilibrium theory of the distribution of rare alleles in a subdivided population. Heredity 56:409-415

> Bossart JL, Prowell DP (1998) Genetic estimates of population structure and gene flow: limitations, lessons and new directions. Trends Ecol Evol 13:202-206

$>$ Brookfield JFY (1996) A simple new method for estimating null allele frequency from heterozygote deficiency. Mol Ecol 5:453-455

Cardoso NA, Le Pendu Y, Lapenta MJ, Raboy BE (2011) Frugivory patterns and seed dispersal by golden-headed lion tamarins (Leontopithecus chrysomelas) in Una biological reserve, Bahia, Brazil. Mammalia 75:327-337

> Chase MW, Hills HH (1991) Silica gel: an ideal material for field preservation of leaf samples for DNA studies. Taxon 40:215-220

Colpaert N, Cavers S, Bandou E, Caron H, Gheysen G, Lowe AJ (2005) Sampling tissue for DNA analysis of trees: trunk cambium as an alternative to canopy leaves. Silvae Genet 54:265-269

> Colwell RK, Mao CX, Chang J (2004) Interpolating, extrapolating, and comparing incidence-based species accumulation curves. Ecology 85:2717-2727

Cornuet JM, Luikart G (1996) Description and power analysis of two tests for detecting recent population bottlenecks from allele frequency data. Genetics 144:2001-2014
Cosson JF, Pons JM, Masson D (1999) Effects of forest fragmentation on frugivorous and nectarivorous bats in French Guiana. J Trop Ecol 15:515-534

> Excoffier L, Slatkin M (1998) Incorporating genotypes of relatives into a test of linkage disequilibrium. Am J Hum Genet 62:171-180

> Excoffier L, Smouse PE, Quattro JM (1992) Analysis of molecular variance inferred from metric distances among DNA haplotypes: application to human mitochondrial DNA restriction data. Genetics 131:479-491

Excoffier L, Laval G, Schneider S (2005) Arlequin ver. 3.0: an integrated software package for population genetics data analysis. Evol Bioinform Online 1:47-50

Fahrig L (2003) Effects of habitat fragmentation on biodiversity. Annu Rev Ecol Evol Syst 34:487-515

Finger A, Kettle C, Kaiser-Bunbury C, Valentin T, Mougal J, Ghazoul J (2012) Forest fragmentation genetics in a formerly widespread island endemic tree: Vateriopsis seychellarum (Dipterocarpaceae). Mol Ecol 21:2369-2382

> Franceschinelli EV, Vasconcelos GMP, Landau EC, Ono KY, Santos FAM (2007) The genetic diversity of Myrciaria floribunda (Myrtaceae) in Atlantic forest fragments of different sizes. J Trop Ecol 23:361-367

> Gotelli NJ, Colwell RK (2001) Quantifying biodiversity: procedures and pitfalls in the measurement and comparison of species richness. Ecol Lett 4:379-391

> Guo SW, Thompson EA (1992) Performing the exact test of Hardy-Weinberg proportion for multiple alleles. Biometrics 48:361-372

> Howe HF, Smallwood J (1982) Ecology of seed dispersal. Annu Rev Ecol Syst 13:201-228

Hubbell S (2004) Two decades of research on the BCI forest dynamics plot. In: Losos E, Leigh EG Jr (eds) Tropical forest diversity and dynamism: findings from a large-scale plot network. University of Chicago Press, Chicago, IL, p 8-30

IUCN (2013) IUCN Red List categories and criteria: version 3.1. IUCN Species Survival Commission, Gland. http:// jr.iucnredlist.org/documents/redlist_cats_crit_en.pdf (accessed 28 Dec 2013)

Jardim JG (2003) Uma caracterização parcial da vegetação na região sul da Bahia, Brasil. In: Prado PI, Landau EC, Moura RT, Pinto LPS, Fonseca GAB, Alger K (eds) Corredor de biodiversidade da Mata Atlântica do sul da Bahia. Instituto de Estudos Sócio-Ambientais do Sul da Bahia e Conservation International do Brasil, Ilhéus (CD-ROM)

Kramer AT, Ison JL, Ashley MV, Howe HF (2008) The paradox of forest fragmentation genetics. Conserv Biol 22: 878-885

Landau EC, Resende NAT, Novaes LAD (2003) Mapa de solos. In: Prado PI, Landau EC, Moura RT, Pinto LPS, Fonseca GAB, Alger K (eds) Corredor de biodiversidade da Mata Atlântica do sul da Bahia. Instituto de Estudos Sócio-Ambientais do Sul da Bahia e Conservation International do Brasil, Ilhéus (CD-ROM)

Landau EC, Hirsch A, Musinsky J (2008) Vegetation cover and landuse in the Atlantic coastal forest of southern Bahia, Brazil, based on satellite imagery: a comparison among municipalities. In: Thomas WW (ed) The Atlantic coastal forest of northeastern Brazil. The New York Botanical Garden Press, New York, NY, p 221-244

Levene H (1949) On a matching problem arising in genetics. Ann Math Stat 20:91-94

Levene $H$ (1960) Robust tests for the equality of variances. In: Olkin I, Ghurye SG, Hoeffding W, Madow WG, Mann 
HB (eds) Contributions to probability and statistics. Stanford University Press, Palo Alto, CA, p 278-292

Loveless MD, Hamrick JL (1984) Ecological determinants of genetic structure in plant populations. Annu Rev Ecol Syst 15:65-95

Luikart G, Allendorf F, Cornuet J, Sherwin W (1998) Distortion of allele frequency distributions provides a test for recent population bottlenecks. J Hered 89:238-247

Mendonça JR, Carvalho AMD, Silva LAM, Thomas WW (1994) 45 anos de desmatamento no sul da Bahia, remanescentes da Mata Atlântica-1945, 1960, 1974, 1990. Projecto Mata Atlântica Nordeste, Centro de Pesquisas do Cacau, Ilhéus

Moraes RCS, Vivas CV, Oliveira FA, Menezes IPP, Berg CVD, Gaiotto FA (2013) Microsatellite markers for an endemic Atlantic forest tree, Manilkara multifida (Sapotaceae). AoB Plants 5:plt006

$>$ Mori SA, Silva LAM (1979) The herbarium of the 'Centro de Pesquisas do Cacau' at Itabuna, Brazil. Brittonia 31: 177-196

Mori SA, Boom BM, Carvalho AMD, Santos TSD (1983) Southern Bahian moist forests. Bot Rev 49:155-232

Myers N, Mittermeier RA, Mittermeier CG, da Fonseca GAB, Kent J (2000) Biodiversity hotspots for conservation priorities. Nature 403:853-858

$>$ Nason JD, Hamrick JL (1997) Reproductive and genetic consequences of forest fragmentation: two case studies of neotropical canopy trees. J Hered 88:264-276

O'Farrill G, Calmé S, Gonzalez A (2006) Manilkara zapota: a new record of a species dispersed by tapirs. Tapir Conserv 15:32-35

> Oetting WS, Lee HK, Flanders DJ, Wiesner GL, Sellers TA, King RA (1995) Linkage analysis with multiplexed short tandem repeat polymorphisms using infrared fluorescence and M13 tailed primers. Genomics 30:450-458

> Oliveira LC, Hankerson SJ, Dietz JM, Raboy BE (2010) Key tree species for the golden-headed lion tamarin and implications for shade-cocoa management in southern Bahia, Brazil. Anim Conserv 13:60-70

Peakall R, Smouse PE (2006) GenAlEx 6: genetic analysis in Excel. Population genetic software for teaching and research. Mol Ecol Notes 6:288-295

Pennington TD (1990) Sapotaceae. Flora neotropica monograph no. 52. New York Botanical Garden, New York, NY

Pennington TD (2004) Sapotaceae (Sapodilla family). In: Smith N, Mori SA, Henderson A, Stevenson DW, Heald SV (eds) Flowering plants of the neotropics. Princeton University Press, Princeton, NJ, p 342-344

Pires-O'Brien J (1998) Manilkara maxima. IUCN Red List of Threatened Species, v.2014.2. www.iucnredlist.org/ details/35614/0 (accessed 13 Jan 2014)

> Piry S, Luikart G, Cornuet JM (1999) BOTTLENECK: A program for detecting recent reductions in effective population size using allele frequency data. J Hered 90:502-503

R Development Core Team (2013) R: a language and environment for statistical computing. $\mathrm{R}$ Foundation for Statistical Computing, Vienna

Raboy BE, Dietz JM (2004) Diet, foraging, and use of space in wild golden-headed lion tamarins. Am J Primatol 63: 1-15

Raymond M, Rousset F (1995) GENEPOP (version 1.2): population genetics software for exact tests and ecumenicism. J Hered 86:248-249

Ribeiro MC, Metzger JP, Martensen AC, Ponzoni FJ, Hirota

Editorial responsibility: Hans Juergen Boehmer,

Bonn, Germany
MM (2009) The Brazilian Atlantic forest: How much is left, and how is the remaining forest distributed? Implications for conservation. Biol Conserv 142:1141-1153

Rocha CFA (1976) Diagnostico socioeconômico da região cacaueira, Vol 5. Recursos hídricos. Comissão Executiva do Plano da Lavoura Cacaueira and the Instituto Interamericano de Ciências Agricolas-OEA, Ilhéus

Rousset F (2008) Genepop'007: a complete re-implementation of the genepop software for Windows and Linux. Mol Ecol Resour 8:103-106

Salgueiro F, Felix D, Caldas JF, Margis-Pinheiro M, Margis R (2004) Even population differentiation for maternal and biparental gene markers in Eugenia uniflora, a widely distributed species from the Brazilian coastal Atlantic rain forest. Divers Distrib 10:201-210

Schneller JJ, Holderegger R (1996) Genetic variation in small, isolated fern populations. J Veg Sci 7:113-120

Seoane CES, Kageyama PY, Sebbenn AM (2000) Forest fragmentation in population genetic structure of Esenbeckia leiocarpa Engl. (Guarantã). Scientia Forestalis 57: 123-139

Seoane CES, Kageyama PY, Ribeiro A, Matias R, Reis M, Bawa K, Sebbenn AM (2005) Efeitos da fragmentação florestal sobre a imigração de sementes ea estrutura genética temporal de populações de Euterpe edulis mart. Revista do Instituto Florestal 17:23-43

Shilton LA, Altringham JD, Compton SG, Whittaker RJ (1999) Old world fruit bats can be long-distance seed dispersers through extended retention of viable seeds in the gut. Proc R Soc Lond B Biol Sci 266:219-223

Silva EF, de Oliveira CAM, Lins-e-Silva ACB, Rodal MJN (2008) Diversity and genetic structure of natural fragmented populations of Tapirira guianensis Aubl. in northeastern Brazil. Bioremediat Biodivers Bioavailab 2: $35-40$

Thomas WW, Barbosa MRDV (2008) Natural vegetation types in the Atlantic coastal forest of northeast Brazil. In: Thomas WW (ed) The Atlantic coastal forest of northeastern Brazil. The New York Botanical Garden Press, New York, NY, p 6-20

van Loon E, Cleary D, Fauvelot C (2007) ARES: Software to compare allelic richness between uneven samples. Mol Ecol Notes 7:579-582

Van Oosterhout C, Hutchinson WF, Wills DP, Shipley P (2004) Micro-checker: software for identifying and correcting genotyping errors in microsatellite data. Mol Ecol Notes 4:535-538

> Van Oosterhout C, Weetman D, Hutchinson W (2006) Estimation and adjustment of microsatellite null alleles in nonequilibrium populations. Mol Ecol Notes 6:255-256

Vogel JC, Rumsey FJ, Russell SJ, Cox CJ and others (1999) Genetic structure, reproductive biology and ecology of isolated populations of Asplenium csikii (Aspleniaceae, Pteridophyta). Heredity 83:604-612

Weir BS (1996) Genetic data analysis II: methods for discrete population genetics data. Sinauer Associates, Sunderland, MA

> Welden CW, Hewett SW, Hubbell SP, Foster RB (1991) Sapling survival, growth, and recruitment: relationship to canopy height in a neotropical forest. Ecology 72:35-50

> Yamamichi M, Innan H (2012) Estimating the migration rate from genetic variation data. Heredity 108:362-363

> Young A, Boyle T, Brown T (1996) The population genetic consequences of habitat fragmentation for plants. Trends Ecol Evol 11:413-418

Submitted: March 24, 2014; Accepted: August 23, 2014

Proofs received from author(s): November 5, 2014 